Agrisaintifika

Jurnal Ilmu-Ilmu Pertanian

Vol. 2, No. 1, 2018

\title{
Pendugaan Umur Simpan Keripik Tempe Sagu dalam Pengemas Aluminium Foil
}

\author{
Afriyanti $^{1}$, Catur Budi Handayani ${ }^{2)}$, Dan A. Intan Niken Tari ${ }^{3)}$ \\ 1,2,3)Fakultas Pertanian, Jurusan Teknologi Hasil Pertanian, Universitas Veteran Bangun Nusantara, \\ JI. Letjend S. Humardani No 1 Jombor Sukoharjo, Telp (0271) 593156, email:afriyantistp@gmail.com
}

\begin{abstract}
ABSTRAK
Keripik tempe sagu adalah salah satu alternatif modifikasi tempe kedelai yang memiliki tekstur yang lebih renyah, penampakan yang lebih menarik dan rasa yang lebih gurih. Tepung tapioka atau biasa disebut tepung sagu menjadi bahan campuran saat proses fermentasi. Kerenyahan produk ini tidak tahan lama jika tidak dikemas dengan pengemas yang sesuai. Tujuan penelitian ini untuk mengetahui umur simpan keripik tempe sagu dalam pengemas aluminium foil dengan metode Arrhenius. Metode penelitiannya dengan penyimpanan produk pada suhu $5^{\circ} \mathrm{C}, 27^{\circ} \mathrm{C}$ dan $50^{\circ} \mathrm{C}$ selama satu bulan. Analisis terhadap kadar air dan kadar asam lemak bebas dilakukan setiap 6 hari sekali. Hasil penelitian menunjukkan bahwa produk keripik tempe sagu yang disimpan dengan pengemas aluminium foil memiliki umur simpan selama 108 hari atau 3,6 bulan.
\end{abstract}

Kata kunci: Aluminium foil, Arrhenius, Keripik tempe sagu

\section{ABSTRACT}

Sago tempe chips are one of the alternative modified from soybean tempeh that has more crispy texture, more interesting appearance and more savory taste. Tapioca flour or commonly called sago powder was mixed with other materials during the fermentation process. The crispness of this product is not durable if it is not packaged with the appropriate packaging. The purpose of this research was to know the shelf life of tempe sago chips in packing aluminum foil with Arrhenius method. The product was stored at $5^{\circ} \mathrm{C}, 27^{\circ} \mathrm{C}$ and $50^{\circ} \mathrm{C}$ for a month. Analysis of water content and free fatty acid content is done every 6 days. The results showed that the sago tempe chips product that was stored with aluminum foil packer had the shelf life for 108 days or 3.6 months.

Keywords: Aluminium foil,Arrhenius method, sago tempe, shelf life.

\section{PENDAHULUAN}

Keripik tempe sagu menjadi salah satu alternatif modifikasi tempe kedelai yang merupakan produk keripik tempe kedelai tetapi dengan tekstur yang lebih renyah, penampakan yang lebih menarik dan rasa yang lebih gurih. Tepung tapioca atau biasa disebut tepung sagu menjadi bahan campuran saat proses fermentasi. Menurut Tursilawati (1999), faktor yang perlu diperhatikan dalam pembuatan keripik adalah tekstur, warna, kandungan minyak dan masa simpannya untuk mempertahankan mutu sensoriknya. Keripik merupakan salah satu produk hasil penggorengan yang sensitif terhadap air dan oksigen sehingga mudah melempem dan tengik. Oleh karena itu dibutuhkan jenis pengemas yang cocok untuk mempertahankan kualitas keripik tempe sagu.

Umumnya produsen keripik tempe sagu menggunakan plastik polipropilen untuk mengemas produk. Namun proses pengemasan yang tidak sempurna menyebabkan keripik menjadi lebih mudah melempem dan tengik (Afriyanti, 2017). Oleh karena itu perlu diteliti penggunaan jenis pengemas yang lain agar produk tidak cepat 
rusak sehingga umur simpan menjadi lebih lama, salah satunya dengan menggunakan aluminium foil.

Keterangan umur simpan (masa kadaluarsa) produk pangan merupakan salah satu informasi yang wajib dicantumkan oleh produsen pada label kemasan produk pangan, terkait dengan keamanan produk pangan dan untuk memberikan jaminan mutu pada saat produk sampai ke tangan konsumen. Kewajiban pencantuman masa kadaluarsa pada label pangan diatur dalam Undang-undang Pangan no.7/1996 serta Peraturan Pemerintah No.69/1999 tentang Label dan Iklan Pangan, dimana setiap industri pangan wajib mencantumkan tanggal kadaluarsa (expired date) pada setiap kemasan produk pangan (Kusnandar, 2010).

Menurut Kusnandar dkk (2010); Anagari dkk, 2011); dan Pranoto dkk (2012), metode pendugaan umur simpan dapat dilakukan dengan metode Accelerated Shelf Life Testing (ASLT) yaitu dengan cara menyimpan produk pangan pada suhu atau kelembaban yang lebih tinggi sehingga produk cepat rusak. Metode akselerasi dapat dilakukan dalam waktu yang lebih singkat dengan akurasi yang baik. Metode ASLT model Arrhenius banyak digunakan untuk pendugaan umur simpan produk pangan yang mudah rusak oleh reaksi kimia, seperti oksidasi lemak, reaksi Maillard, denaturasi protein dan sebagainya. Suhu yang tinggi akan menyebabkan laju reaksi kimia semakin tinggi sehingga produk akan lebih cepat mengalami kerusakan. Salah satu produk pangan yang dapat ditentukan umur simpannya dengan model Arrhenius adalah produk chips/snack dan produk pangan lain yang mengandung lemak tinggi (berpotensi terjadinya oksidasi lemak), atau yang mengandung gula pereduksi dan protein (berpotensi terjadinya reaksi browning). Model Arrhenius ini menggunakan data perubahan parameter mutu selama penyimpanan.

Manfaat dari penelitian ini adalah mengetahui umur simpan keripik tempe sagu dengan pengemas aluminium foil sehingga dapat digunakan sebagai alternatif pilihan selain pengemas plastik.

\section{BAHAN DAN METODE}

\subsection{Bahan}

Bahan baku yang digunakan adalah keripik tempe sagu yang diperoleh dari Tawangsari Sukoharjo. Kemasan aluminium foil diperoleh dari Pasar Gedhe Surakarta.

\subsection{Metode}

Metode yang digunakan dalam penelitian ini mengacu pada metode penelitian Afriyanti (2017). Keripik tempe sagu yang diperoleh dari produsen di daerah Tawangsari, Sukoharjo ditimbang masing-masing 100 gram. Kemudian dikemas dalam pengemas aluminium foil sebanyak 30 bungkus. Sebanyak 10 kemasan disimpandalam suhu $5^{\circ} \mathrm{C}, 10$ kemasan yang sama dalam suhu $27^{\circ} \mathrm{C}$ dan 10 kemasan disimpandalam suhu $50^{\circ} \mathrm{C}$. Sebelum penyimpanan dilakukan pengukuran kadar air dan kadar asam lemak bebas (FFA). Hasilnya digunakan sebagai kontrol. Setiap 6 hari sekali dilakukansampling untuk dilakukakan analisis seperti pada kontrol.

Dari hasil pengamatan kripik tempe sagu terhadap waktu akan diplotkan dan didapatkan 3 persamaan regresi yang didapat dari 3 suhu penyimpanan yang berbeda, tiap-tiap persamaan akan didapatkan nilai slope (b) dan nilai konstanta (k). Untuk pendekatan Arrhenius nilai k diplotkan dengan $1 / \mathrm{T}(\mathrm{K}-1)$ dan In $\mathrm{K}$ yang merupakan intersep dan slope dari persamaan regresi linier $\mathrm{In}$ $k=$ In $k 0-(E / R)(1 / T)$ dengan In k0 adalah intersep, $E / R$ adalah slope, Ea adalah energi aktivasi dan $\mathrm{R}$ adalah konstanta gas ideal yaitu $1.986 \mathrm{kal} / \mathrm{mol}^{0}$ $\mathrm{K}$. $\mathrm{Mol}^{0} \mathrm{~K}$. Setelah didapatkan nilai k0 yang merupakan faktor preeksponensial dan nilai energi aktivasi reaksi perubahan karakteristik keripik tempe sagu dimana $E A=E$, maka akan didapatkan persamaan Arrhenius yang merupakan persamaan laju reaksi perubahan karakteristik perubahan keripik tempe sagu dengan persamaan $k-k 0 . e-E / R T$ dengan $T$ 
adalah suhu penyimpanan. Dengan persamaan Arrhenius yang didapat, maka dapat dihitung nilai konstanta Arrhenius dengan masing-masing suhu penyimpanan. Parameter yang memiliki nilai energi aktivasi yang terendah merupakan parameter kunci. Umur simpan dihitung menggunakan persamaan reaksi berdasarkan orde reaksinya. Untuk penentuan umur simpan keripik tempe sagu adalah dengan memasukkan nilai suhu ke dalam persamaan In $k=\ln k 0-(E / R)$ $(1 / T)$. Nilai $k$ yang didapat dimasukkan dalam persamaan orde reaksi untuk mendapatkan umur simpan keripik tempe sagu (Swadana dan Yuwono, 2014).

\section{HASIL DAN PEMBAHASAN}

Pada pendugaan umur simpan suatu produk perlu dilakukan pengujian parameter yang mempengaruhi mutu produk sebelum disimpan untuk periode tertentu. Parameter tersebut meliputi kadar air dan kadar asam lemak bebas. Parameter-parameter tersebut dianalisa pada awal penyimpanan sebagai hari ke-0. Kondisi pengemasan keripik tempe sagu dapat dilihat pada Gambar 1.

Keripik tempe sagu yang digunakan dalam penelitian ini merupakan hasil produksi dari produsen keripik tempe sagu di daerah Tawangsari, Sukoharjo. Biasanya, produk ini dikemas menggunakan plastik polipropilen (Gambar 2).

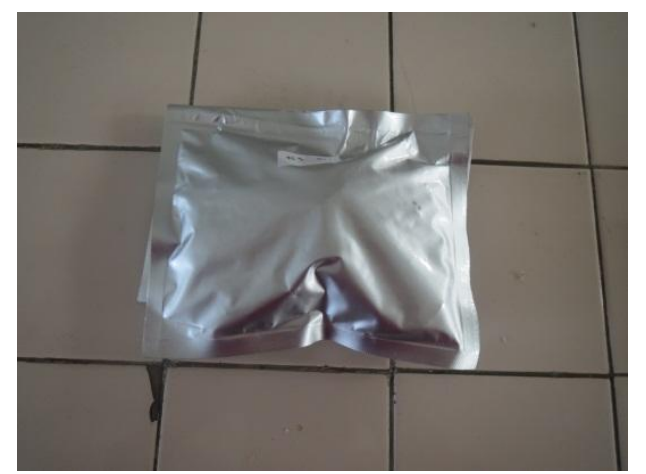

Gambar 1. Keripik Tempe Sagu Dikemas Dengan Aluminium Foil

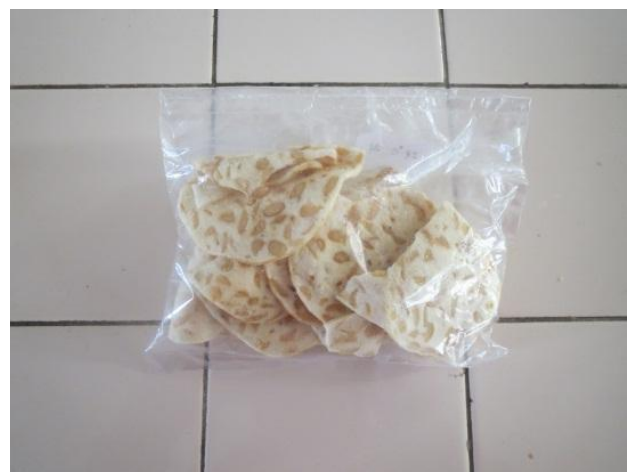

Gambar 2. Keripik Tempe Sagu Dikemas Dengan Plastik Polipropilen (Afriyanti, 2017)

\subsection{Kadar Air}

Secara umum, kadar air keripik tempe sagu mengalami kenaikan selama penyimpanan. Hubungan antara lama penyimpanan dengan perubahan kadar air dapat dilihat pada Gambar 3. Tabel 1 menunjukkan persamaan regresi linier yang didapatkan dari grafik perubahan kadar air keripik tempe sagu selama penyimpanan. Grafik persamaan Arrhenius didapatkan dari hasil nilai $\mathrm{ln} \mathrm{k}$ yang diplotkan dengan nilai kebalikan suhu mutlak. Hasil ini dapat dilihat pada Gambar 4.

Persamaan regresi linear dari plot In $\mathrm{k}$ dan $1 / T$ pada perubahan kadar air keripik tempe sagu pengemas aluminium foil yaitu $y=$ $-3108.2 x+4.6062$ dengan $R^{2}=0.2688$. Energi aktivasi (Ea) perubahan kadar air sebesar $6172.89 \mathrm{kal} / \mathrm{mol}$ yang artinya untuk memulai terjadinya perubahan kadar air diperlukan energi sebesar tersebut. Kandungan air dalam produk tetap menguap namun karena pengemasan yang hermetis membuat uap air tersebut tidak dapat keluar dari kemasan sehingga tertahan di permukaan dalam kemasan dengan terbentuk titik-titik uap air. Kemasan hermetis mampu mempertahankan gas dan uap air yang berasal dari dalam maupun dari luar kemasan (Haryati et al, 2015).

\subsection{Kadar Asam Lemak Bebas}

Pengemas aluminium foil merupakan pengemas yang tahan terhadap pengaruh suhu dan kedap udara, sehingga mampu 
menghambat gas yang masuk ke dalam pengemas. Hal ini mampu mengurangi kerusakan asam lemak pada produk keripik tempe sagu. Data menunjukkan bahwa suhu dan lama penyimpanan memberikan pengaruh yang nyata terhadap perubahan kadar asam lemak bebas pada keripik tempe sagu. Grafik perubahan kadar asam lemak bebas keripik tempe sagu selama penyimpanan satu bulan dengan tiga suhu yang berbeda dapat dilihat pada Gambar 5 . Tabel 2 menunjukkan persamaan regresi linier yang didapatkan dari grafik perubahan kadar asam lemak bebas keripik tempe sagu selama penyimpanan. Grafik persamaan Arrhenius didapatkan dari hasil nilai In $\mathrm{k}$ yang diplotkan dengan nilai kebalikan suhu mutlak. Hasil ini dapat dilihat pada Gambar 6.

Persamaan regresi linear dari plot In $k$ dan $1 / T$ pada perubahan kadar asam lemak bebas keripik tempe sagu pengemas aluminium foil yaitu $y=-1266.6 x+0.7247$ dengan $\mathrm{R}^{2}=0.8778$. Energi aktivasi (Ea) perubahan kadar air sebesar $2515.47 \mathrm{kal} / \mathrm{mol}$ yang artinya untuk memulai terjadinya perubahan kadar asam lemak bebas diperlukan energi sebesar tersebut. Nilai energi aktivasi ini lebih kecil dibandingkan dengan nilai energi aktivasi perubahan kadar air.

\subsection{Penentuan Umur Simpan}

Penelitian umur simpan keripik tempe sagu ini menggunakan metode Accelerated Shelf Life Testing (ASLT). Metode ini menggunakan kondisi suatu kondisi lingkungan yang dapat mempercepat terjadinya reaksi-reaksi penurunan mutu produk pangan (Labuza, 1982). Dalam penentuan laju reaksi penurunan mutu yang menggunakan suhu sebagai salah satu parameter untuk mempercepat kerusakan, maka laju penurunan mutunya dapat ditentukan berdasarkan pada energi aktivasinya. Energi aktivasi adalah energi yang diperlukan untuk memulai suatu reaksi.
Penelitian ini menggunakan kadar air dan kadar asam lemak bebas sebagai parameter yang mempengaruhi penurunan mutu keripik tempe sagu selama penyimpanan. Menurut Herawati (2008) faktor yang berpengaruh nyata pada penurunan mutu produk adalah perubahan kadar air dalam produk dan menurut Saleh et al (2013), kadar air merupakan variabel yang diketahui adalah parameter kritis masa kedaluwarsa suatu produk.

Diantara parameter tersebut dipilih satu parameter untuk menghitung umur simpan keripik tempe sagu dimana parameter tersebut dianggap sangat mempengaruhi penurunan mutu keripik tempe sagu selama penyimpanan (Afriyanti, 2017). Parameter yang digunakan tersebut adalah parameter yang mempunyai nilai energi aktivasi terendah karena semakin rendah energi yang dibutuhkan untuk memulai reaksi kerusakan lebih rendah sehingga reaksi kerusakan akan berlangsung lebih lama. Jika energi aktivasi tinggi maka energi yang dibutuhkan untuk memulai reaksi kerusakan lebih tinggi dan reaksi kerusakan akan berlangsung lebih cepat (Swadana dan Yuwono, 2014). Dalam penelitian ini parameter perubahan kadar asam lemak bebas dalam kemasan aluminium foil memiliki nilai energi aktivasi lebih rendah dibandingkan kadar air.

Berdasarkan persamaan linier dan energi aktivasi perubahan kadar asam lemak bebas keripik tempe sagu pengemas aluminium foil didapatkan umur simpan selama 108 hari atau sekitar 3.6 bulan,. Hasil penelitian Afriyanti (2017) menunjukkan bahwa keripik tempe sagu yang disimpan dengan pengemas plastik polipropilen memiliki umur simpan yang lebih rendah yaitu 91 hari. Hal ini menunjukkan bahwa pengemas aluminium foil mampu melindungi produk olahan minyak seperti keripik dengan lebih baik dibandingkan plastik polipropilen karena struktur kemasan yang lebih tebal dan kedap udara sehingga mampu melindungi produk dari masuknya air dan udara dari lingkungan. 
Afriyanti, et al. 2018

Hasil penelitian Desmelati et al (2013) juga menunjukkan bahwa aluminium foil merupakan pengemas terbaik untuk produk dendeng ikan dibandingkan dengan plastik HDPE dan LDPE.

\section{KESIMPULAN}

Perubahan kadar asam lemak bebas keripik tempe sagu selama penyimpanan lebih berpengaruh terhadap umur simpan produk dibandingkan perubahan kadar air. Keripik tempe sagu dengan pengemas aluminium foil mampu mempertahankan kualitasnya selama 3,6 bulan.

\section{DAFTAR PUSTAKA}

Afriyanti. 2017. Pendugaan Umur Simpan Keripik Tempe Sagu Menggunakan Pengemas Plastik PP dengan Metode Arrhenius. Jurnal Ilmu Pangan dan Hasil Pertanian Vol. 1 No. 1 Thn. 2017

Anagari, et al. 2011. Penentuan Umur Simpan Minuman Fungsional Sari Akar Alangalang dengan Metode Accelerated Shelf Life Testing (ASLT) (Studi Kasus di UKM "R.Rovit" Batu - Malang). Agrointek 5 (2) : 118 - 125.

Desmelati, et al. 2013. The Influence of Different Packaging Materials on Quality of Pangasius Catfish Dendeng (Pangasius Hypopthalmus) Stored At Room Temperature. Berkala Perikanan Terubuk, Vol 41, No 1 Februari 2013, hlm 53-61.

Haryati et al. 2015. Pendugaan Umur Simpan Menggunakan Metode Accelerated Shelf Life Testing (ASLT) dengan Pendekatan Arrhenius pada Produk Tape Ketan Hitam Khas Mojokerto Hasil Sterilisasi. Jurnal Pangan dan Agroindustri Vol 3 No 1 p 156-165, Januari 2015.
Herawati, H. 2008. Penentuan Umur Simpan pada Produk Pangan. Jurnal Litbang Pertanian 27(4), 2008.

Kusnandar, Fei. 2010. Pendugaan Umur Simpan Metode ASLT. http://itp.fateta.ipb.ac.id/id/index.php?opt ion=com_content\&task=view\&id=86\&Ite mid=94. Online 13 Maret 2015.

Labuza, T.P and Riboh, D. 1982. Theory and Application of Arrhenius Kinetics to the Prediction of Nutrien Losses in Food. Food Technology 36: 66-74.

Pranoto, et al. 2012. Perkiraan Umur Simpan Kacang Rendah Lemak Dilapisi dengan Carboxymethyl Cellulose Menggunakan Metode Accelerated Shelf-life Test (ASLT). AGRITECH, Vol. 32, No. 3, AGUSTUS 2012.

Saleh, et al. 2013. Prediksi Masa Kedaluwarsa Wafer dengan Artificial Neural Network (ANN) berdasarkan Parameter Nilai Kapasitansi. Agritech 33 (4) : $450-457$.

Swadana dan Yuwono. 2014. Pendugaan Umur Simpan Minuman Berperisa apel Menggunakan Metode Accelerated Shelf Life Testing (ASLT) dengan Pendekatan Arrhenius. Jurnal Pangan dan Agroindustri Vol 2 No 3 p 203-213, Juli 2014.

Tursilawati, R.A. 1999. Pengurangan Absorbsi Minyak pada Pembuatan Tempe Chip: Pengaruh Penggunaan Carboxy Methil Cellulose (CMC) dan Pengenceran Adonan Tepung Pelapis. Skripsi. Fakultas Pertanian Unsoed Purwokerto. 
Agrisaintifika

Jurnal Ilmu-Ilmu Pertanian

Vol. 2, No. 1, 2018

Afriyanti, et al. 2018

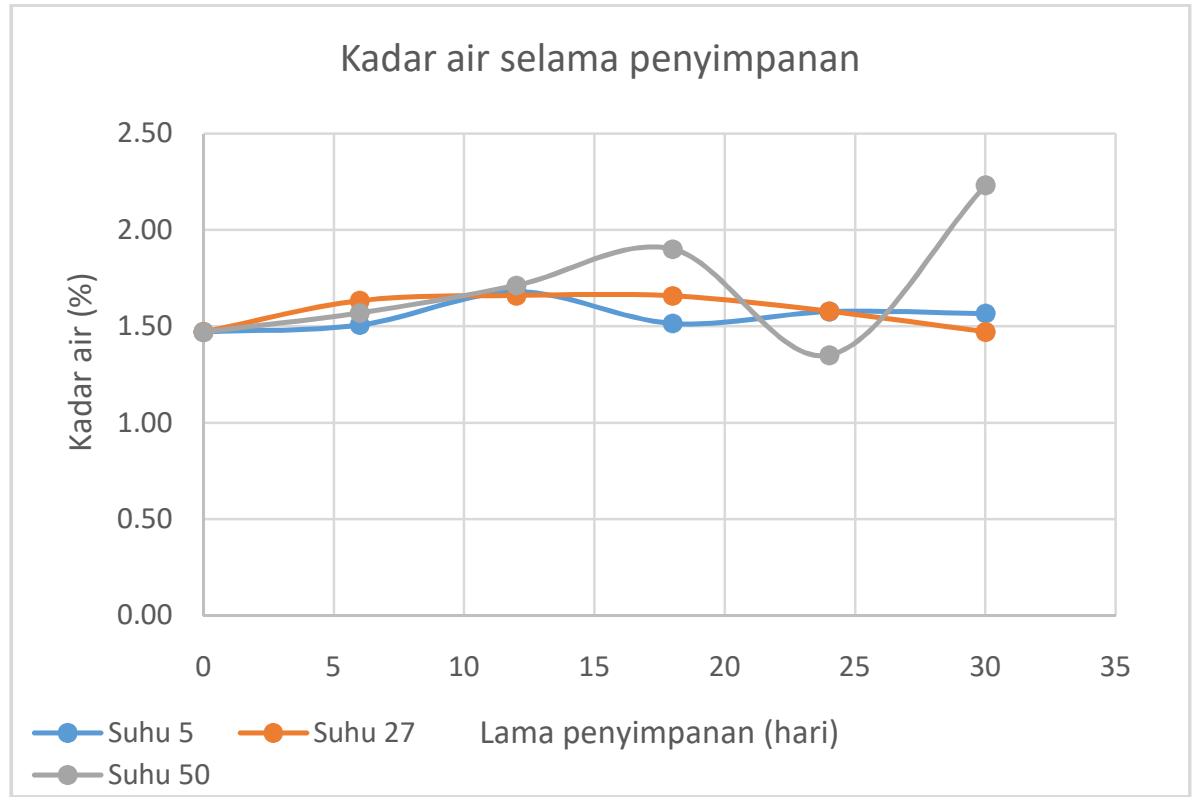

Gambar 3. Grafik Hubungan Antara Lama Penyimpanan Dengan Perubahan Kadar Air Keripik Tempe Sagu Pengemas Aluminium Foil

Tabel 1. Persamaan Linier Perubahan Kadar Air Keripik Tempe Sagu Pengemas Aluminium Foil Selama Penyimpanan, Nilai k, In k dan 1/T

\begin{tabular}{cccccc}
$\begin{array}{c}\text { Suhu } \\
\text { penyimpanan } \\
\text { (TOCelcius) }\end{array}$ & $\begin{array}{c}\text { Suhu } \\
\text { penyimpanan } \\
\text { (T Kelvin) }\end{array}$ & $\begin{array}{c}\text { Persamaan regresi } \\
\text { linier }\end{array}$ & Nilai k & In k & $1 / \mathrm{T}$ \\
\hline 5 & 278 & $\mathrm{y}=0.0025 \mathrm{x}+1.5147$ & 0.0025 & -5.9915 & 0.0036 \\
27 & 300 & $\mathrm{y}=-0.0008 \mathrm{x}+1.5899$ & 0.0008 & -7.1309 & 0.0033 \\
50 & 323 & $\mathrm{y}=0.0159 \mathrm{x}+1.4671$ & 0.0159 & -4.1414 & 0.0031 \\
\hline
\end{tabular}

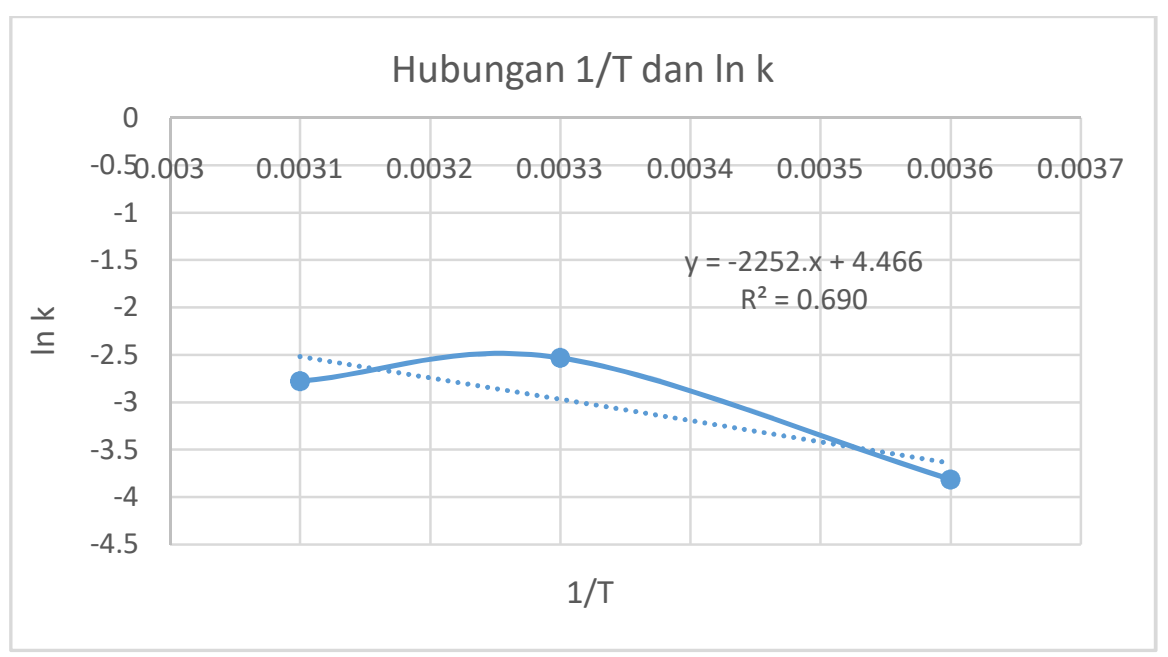

Gambar 4. Hubungan 1/T dan In k dari Kadar Air Keripik Tempe Sagu Pengemas Aluminium Foil 
Agrisaintifika

Jurnal Ilmu-Ilmu Pertanian

Vol. 2, No. 1, 2018

Afriyanti, et al. 2018

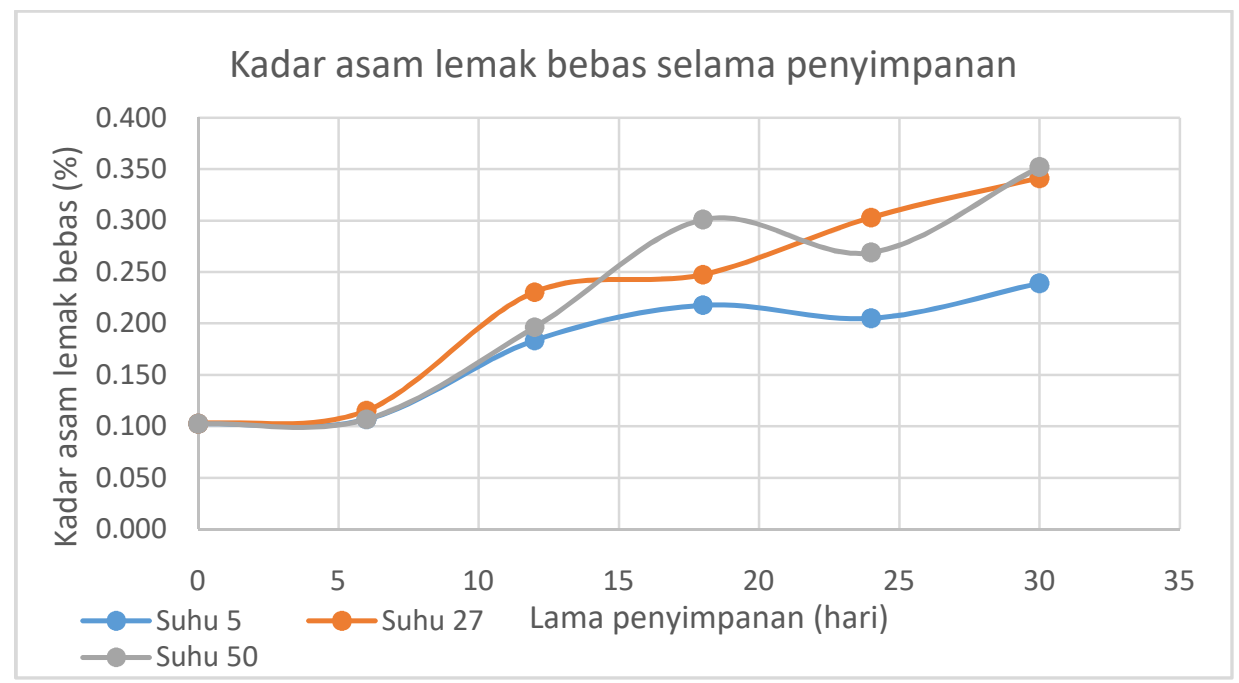

Gambar 5. Grafik Hubungan Antara Lama Penyimpanan Dengan Perubahan Kadar Asam Lemak Bebaskeripik Tempe Sagu Pengemas Aluminium Foil

Tabel 2. Persamaan Linier Perubahan Kadar Asam Lemak Bebas Keripik Tempe Sagu Pengemas Aluminium Foil Selama Penyimpanan, Nilai k, In k dan 1/T

\begin{tabular}{cccccc}
$\begin{array}{c}\text { Suhu } \\
\text { penyimpanan } \\
\left(\mathrm{T}^{0} \text { Celcius }\right)\end{array}$ & $\begin{array}{c}\text { Suhu } \\
\text { penyimpanan } \\
\text { (T Kelvin) }\end{array}$ & $\begin{array}{c}\text { Persamaan regresi } \\
\text { linier }\end{array}$ & Nilai k & ln $\mathrm{k}$ & $1 / \mathrm{T}$ \\
\hline 5 & 278 & $\mathrm{y}=0.0048 \mathrm{x}+0.1034$ & 0.0048 & -5.339 & 0.0036 \\
27 & 300 & $\mathrm{y}=0.0085 \mathrm{x}+0.0339$ & 0.0085 & -4.768 & 0.0033 \\
50 & 323 & $\mathrm{y}=0.0088 \mathrm{x}+0.0316$ & 0.0088 & -4.733 & 0.0031 \\
\hline
\end{tabular}

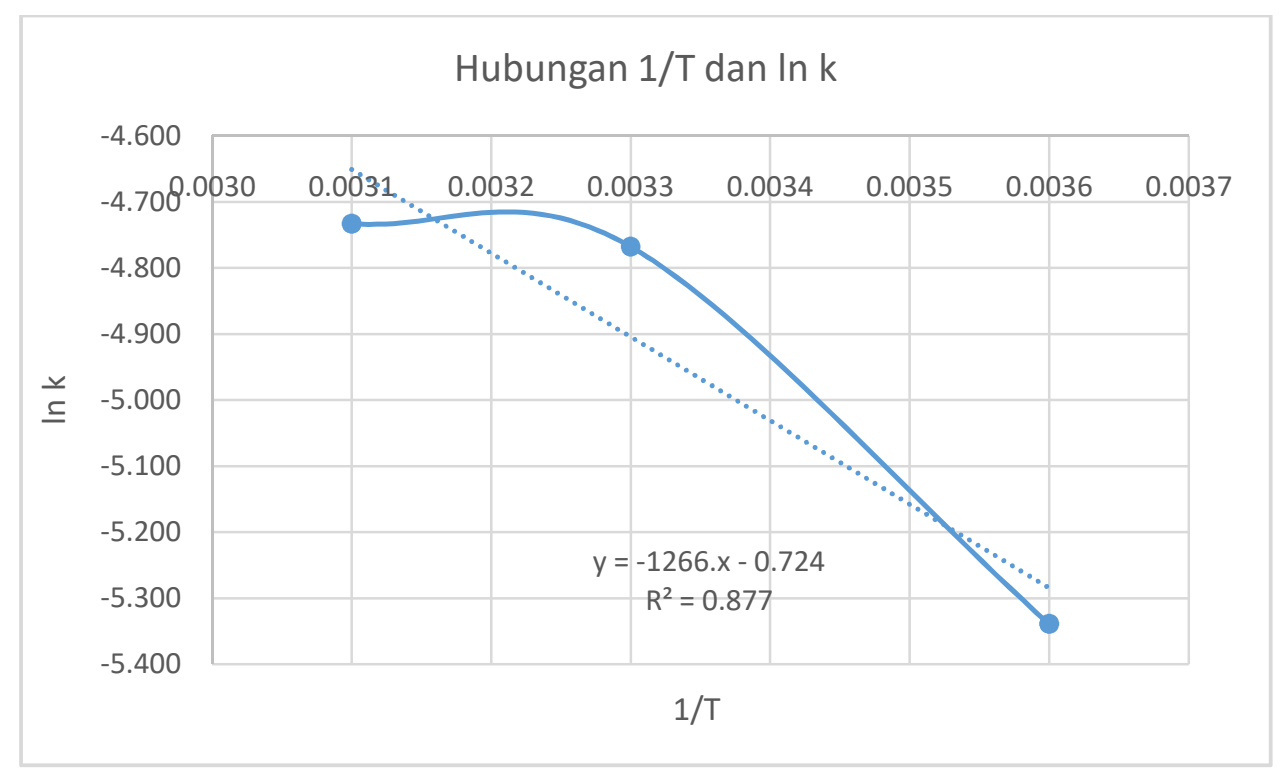

Gambar 6. Hubungan 1/T dan In k dari Kadar Asam Lemak Bebas Keripik Tempe Sagu Pengemas Aluminium Foil 